\title{
Waduk Jatigede: microfinance, rich and poor, poverty and local wisdom
}

\author{
Dr. Junardi Harahap ${ }^{1, *}$ \\ *Department of Anthropology, Faculty of Social and Political Sciences, Padjadjaran University; \\ *Corresponding author: junardiharahap@gmail.com
}

\section{ABSTRACT}

Development is a necessity that brings many benefits to the community. Indeed, the purpose of development is to provide welfare and benefits to the people and the society. The construction of Waduk Jatigede has a very good purpose, which is to provide welfare to the community, especially for irrigation in several districts in West Java. On the one hand, the effect of development also does not lead to positive change, but on the other hand, it also leads to negative influences. That is the aim of this study, to investigate the factors that bring out any positive and negative effects of such developments and to identify the positive and negative effects of the construction of Waduk Jatigede. The questions of this study are regarding the positive and negative influences that rise with the construction of Waduk Jatigede. The study used the qualitative method by conducting interviews and observations. Data were obtained through the support of the Academic Leadership Grant (ALG) Jatigede, Padjadjaran University. The results of the study show that the community does not become prosperous with the construction of Waduk Jatigede and the emergence of new entrepreneurs who become the new rich of the more developed microfinance. However, on the negative side of this development is the presence of the people who became poor due to this project since they do not have other skills than farming or their previous profession. In addition, there are various losses of local wisdom such as regarding health, religion and also of the history of places which was submerged.

Keywords: anthropology, development, local wisdom, microfinance

\section{INTRODUCTION}

Waduk Jatigede (Jatigede Reservoir) is a government program that inevitably has to be implemented and followed by the people who live around the area. People have become aware to follow the program that is managed by the government whether they like it or not. The construction of this kind of program is actually performed by all countries around the world. The society has its own views on all sorts of development provided by the government. Development is a model that has become an integral part of community life. The community generates diverse phenomenon in causing changes in social life and views. Development is a continuation of various programs fully supported by the government and local communities that have an impact on such development. Furthermore, development is like two sides of a coin, contradictory on one side bringing many benefits, but on the other side leading to changes.

Society is a foundation that brings about many changes that will necessarily benefit the society. The influence of society and culture will be of benefit to the people. Community, society and development are affecting the community and leading to a lot of influence on society. Furthermore, society and development is a process that will have an impact to the community, to the people. It brings out changes in society, due to the construction carried out by development.

Meanwhile, society is an object of development which sometimes leads to changes good for society as a result of implementation of the construction. Sometimes it will also lead to changes that are not beneficial to development. What should be done by the public is to accept the program as 
a consequence of development and implement it. However, this could lead to many problems for the communities which have become the object of development.

Development which has led to many changes that benefits our society who really need the concept of development and good results from the development itself. Meanwhile, development is actually an endeavor that is carried out to make the public become more advanced and provides benefits to development and also to the people who will benefit from the development itself. Consequently, it will lead to a lot of changes for the community and also for most of the surrounding communities affected by the construction itself. Society has its own way to define development that will generate major changes to society and also to the community. It defines development as a process leading to a big change for the people of Indonesia, who are part of society, and bringing about changes inside as well as outside society. In addition, various research reports as well as the article about Jatigede has been written by Harahap (2016); Harahap (2015) \& Suwartapradja et al. (2015) reporting about Jatigede from various aspects which give a true picture about occurrences in Jatigede, through research and articles that became the forerunner of articles written today.

\section{LITERATURE REVIEW}

A number of studies have been conducted about the impact of development or resettlement, one of them is a study conducted by Abdullah et al. (2016: 148) who state that resettlement that hit the people has caused them lose the revenue they previously received. In addition, the problem is that they do not feel as comfortable as in the dwellings they have occupied in their original place. However, the most important in the study conducted by Abdullah et al. (2016: 149) is that they experienced a loss of revenue from the income they previously received in their native place before the resettlement and they also lost an assortment of plants and are missing the culture.

According to Carrasco, Ochiai \& Okazaki (2016: 47), the resettlement is carried out with the involvement of various parties to be able to monitor and evaluate, so that there will no injured party when the project is implemented. In a study conducted by Cavalheiro \& Abiko (2015: 346), they suggest that there should be an evaluation of the cases that occur as a result of resettlement especially in the cases that have led to massive changes due to displacement of the community.

Additionally, Abdullah, Borhan \& Ahmad (2015: 77) provide information on the research conducted by them that resettlement occurring in a society has caused social and cultural impacts to the community. Indeed if we see, have the effects generate social and cultural issues to the community due to the influence brought about by the resettlement that occurs in society? These things have to do with culture, and policies are always aside the communities that are affected by the construction and resettlement.

Furthermore, Owen \& Kemp (2015: 485) argue that the affected community of this development is the community that is part of the scenario affected by the length of the impact of development. Since they are people who are also affected by the crisis, they should be aided and addressed so that they can be empowered and become an economically empowered community. According to Okada et al. (2014: 29), the question that struck on the development of resettlement implementation is the psychological influence which has affected people to such development. It is hard to cure the psychological impact because it is psychological and affects the community. Furthermore, Claudianos (2014: 314) contends that in a resettlement there are problems that occurred when people migrate because they are exposed to the impact of resettlement. They are the people who are affected right from the government programs which come as a blow to them because they are affected by such development.

\section{METHOD}

This study is using the qualitative method by conducting in-depth interviews and observations to the Waduk Jatigede. This study is also part of a research of the Academic Leadership Grant (ALG) Jatigede, Padjadjaran University. The data collection is obtained by 
visiting the location of the object the Waduk Jatigede and conducting interviews and observations to those affected by the construction of the Waduk Jatigede.

\section{RESULTS AND DISCUSSION}

Development will bring to the community for the better and there is no development which makes the community worse. Those words are the slogan that is often transmitted by the government's policy makers of development. In order to make communities understand government policies that development does not always benefit the government only, that there are usually negative things that actually harm society itself, which is said to be affected by the development. A part of the people also realizes that development also has much positive impact on the community which will provide many benefits. Such gains will be fulfilled with the availability of water for irrigation and agricultural irrigation sharing.

The analysis of the Waduk Jatigede construction is from the perspective of development that is well developed and changed which form the basis of development. We will look at the impact caused by the construction, which can be seen from the positive and negative outlook. The analysis of the study and the study results are developed in the points in the concept of development and produce a financing and development of a business that empowers the affected communities and causes changes which are good for the community. This has later developed into a model that is quite appropriate, and there are also experiences of poverty caused by the construction. There are also vulnerable people exposed to problems due to the development so that it becomes a small community that are poor and helpless.

\section{MICROFINANCE}

Those who benefited from the construction of the Waduk Jatigede, with the development of the new microfinance will make them become people who excel and are able to take opportunity of the limitations that exist as a result rather than the construction of the Waduk Jatigede. The Waduk Jatigede construction has affected people by experiencing a process of enlightenment and efforts to get out of problems. The results reveal that they become economically empowered communities as well as selfemployed and develop a new endeavor that resulted in the development of the central and central-bank new business in the community.

\section{Picture 1. Jatigede Dam Project}

\section{RICH AND POOR}

Society is getting poorer because people who are not adaptive and do not have expertise beside their original expertise as a farmer will cause them a lot of trouble and make them poorer due to the circumstances that hit them. People are powerless and victimized of the construction and turn them into an apathetic public, and people become poor. They live on one of the financial assistance from the government which later was depleted because it is used for consumptive things only. Thus people become poor and powerless, people become economically dependent, become a very apathetic society, and become people who are totally helpless.

\section{POVERTY}

Poverty has made society into communities that are affected by the construction to the detriment of the community in many facets. This means that the construction of the Waduk Jatigede has led to considerable problems that are very problematic for people who do not have the expertise and the ability to adapt to the environment and also to occurrences due to the construction. This issue becomes then the root of problems of development, which leads to a static society that without change. What happens is that poverty continues to grow and leads to poverty to the people affected by the construction of the Waduk Jatigede. This is what generates many problems. This means that development has led to negative issues, giving rise to the increase of poverty again.

\section{LOCAL WISDOM}

On big problem of the development of the Waduk Jatigede is that a lot of damage of a variety of cultural diversity and local knowledge are slowly dissolved, and its sustainability is questionable. Lots of local 
wisdom ought to be maintained. However, the impact of resettlement has caused many customs, and local knowledge disappear. Many aspects of culture which then gradually disappeared are reinstated. This should be considered carefully. Furthermore, there must be rigorous efforts to maintain the local wisdom which exist in our society. Various arts, and also the customs of the local community will slowly disappear along with the disappearance of the former region that has been turned into a water reservoir area which certainly does not have a cultural life. Culture that perished on the mainland is very different from the culture that has contemplated water to keep the preservation of the cultural wisdom.

\section{CONCLUDING REMARK}

The conclusion that can be drawn from this paper is that the construction of the Waduk Jatigede has a positive as well as a negative impact such as, to the development of new businesses or we can say as a new microfinance that has developed and started up. However, it is very different from those affected who cannot rise from the problems that occurred, thus become the new poor and the problem is quite complicated. The conclusions illustrate that people will always make changes as a result of development Additionally, some people are not adaptive to changes in the role as people who are run over and have lost their opinions, than the actual meaning of development which is the development of a method to achieve better conditions.

\section{ACKNOWLEDGEMENT}

A big appreciation to the Department of Anthropology, Faculty of Social and Political Sciences, Padjadjaran University and author, and also to the Academic Leadership Grant (ALG) Jatigede, Padjadjaran University for providing data that are used as material in this article.

\section{REFERENCE}

Abdullah, J., Sayuti, M.N., Arshad, M.A.A., \& Embong, R.M. (2016). Living Conditions in Orang Asli Resettlement Project (PROSDET) of Pantos, Pahang, Malaysia.
Procedia - Social and Behavioral Sciences, 222, 143-150.

Abdullah, J., Borhan, A.M., \& Ahmad, B.C.(2015).Orang Asli

Resettlement in Urban Environment at Bukit Lanjan, Selangor, Malaysia. Procedia Social and Behavioral Sciences, 201, 71-79.

Carrasco, S., Ochiai, C., \& Okazaki, K. (2016). Disaster Induced Resettlement: Multi-stakeholder Interactions and Decision Making Following Tropical Storm Washi in Cagayan de Oro, Philippines. Procedia - Social and Behavioral Sciences, 218, 35-49.

Cavalheiro, C.D.D., \& Abiko, A. (2015). Evaluating slum (favela) resettlements: The case of the Serra do Mar Project, São Paulo, Brazil. Habitat International, 49, 340-348.

Claudianos, P. (2014). Out of Harm's Way; Preventive Resettlement of at Risk Informal Settlers in Highly Disaster Prone Areas. Procedia Economics and Finance, 18, 312319.

Harahap, J. (2016). Naturalistic Concept of Disease in the Community Jatigede. Bandung: Proceedings The 5th Padjadjaran International Nursing Conference 2016. Padjadjaran University, Faculty of Nursing.

Harahap, J. (2015). Perception of Illness and Communication Medical Residents Affected Resettlement Programme Jatigede. Bandung: E-Prosedings International Conference on Transformation in Communication (IcoTiC 2015).

Owen, R.J., \& Kemp, D. (2015). Review Article. Mining-induced displacement and resettlement: a critical appraisal. Journal of Cleaner Production, 87, 478-488.

Suwartapradja, O.S., Rajab, B., Soemarwoto, S.R., Harahap, J., E., Wikara, K.E., Salman, B.L., Harja, A., Hermawati, R., \& Indrawardana, I. (2015). Laporan Akhir. Hibah Penugasan Penelitian Unggulan 
Academic

Leadership

Grant(ALG) (PROGRAM 1-1-6).

Pemukiman Kembali

(Resettlement) Penduduk Yang

Terkena Pembangunan Waduk

Jatigede di Kabupaten Sumedang

Jawa Barat. Jatinangor:

Universitas Padjadjaran.

\section{Picture 1. Jatigede Dam Project}

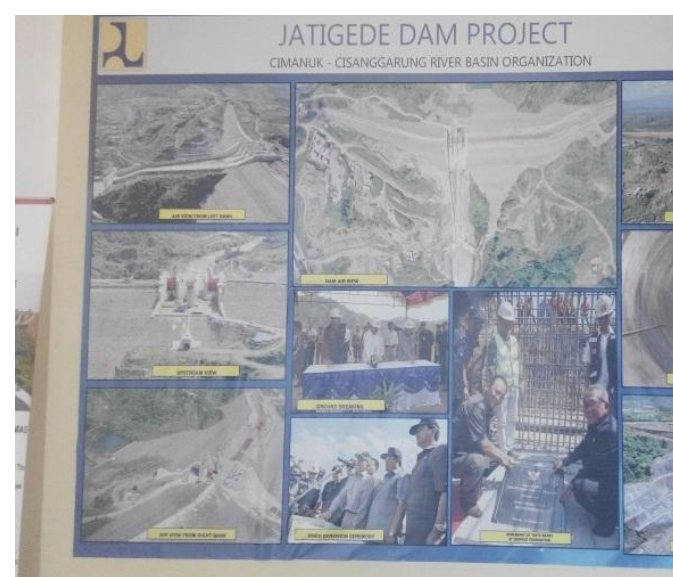

Source: Image at the research site
Okada, T., Haynes, K., Bird, D., Honert, D.V.R., \& King, D. (2014). Recovery and resettlement following the 2011 flash flooding in the Lockyer Valley. International Journal of Disaster Risk Reduction, 8, 20-31. 